\title{
Calculations of exergy for organisms
}

\author{
Sven Erik Jørgensen ${ }^{\mathrm{a}, *}$, Niels Ladegaard ${ }^{\mathrm{b}}$, Marko Debeljak ${ }^{\mathrm{c}}$, Joao Carlos Marques ${ }^{\mathrm{d}}$ \\ ${ }^{a}$ Institute A, Environmental Chemistry, DFU, University Park 2, 2100 Copenhagen $\emptyset$, Denmark \\ ${ }^{\mathrm{b}}$ Langkaer Vaenge 9, Vaerløse 3500, Denmark \\ ${ }^{\mathrm{c}}$ Department of Knowledge Technologies, Josef Stefan Institute, Jamova 39, SI 1000, Slovenia \\ ${ }^{\mathrm{d}}$ Department of Zoology, Faculty of Sciences and Technology, Institute of Marine Research, IMAR, University of Coimbra, 3004-517 \\ Coimbra, Portugal
}

Received 8 March 2004; accepted 29 November 2004

\begin{abstract}
Exergy estimations based on biomass and information for organisms can with good approximation be found as: $\mathrm{Ex}=\beta c$, where $c$ is the concentration of biomass and $\beta$ the weighting factor, that accounts for the information that the organisms carry [Jørgensen, S.E., 2002. Integration of Ecosystem Theories: A Pattern, vol. 432, 3rd ed. Kluwer Academic Publishing Company, Dordrecht, The Netherlands]. The determination of $\beta$ for various organisms has been based on the number of coding genes, but recent research has shown that some of the non-coding genes are crucial for the control, maintenance and development of the organisms. The results [Eichler, E.E., Sankoff, D., 2003. Structural dynamics of eukaryotic chromosome evolution. Science 301, 793-797.] of ongoing whole-genome projects have therefore be applied in order to obtain more accurate $\beta$-values. These new $\beta$-values are several times bigger than the previously applied values. The number of amino acids coding per gene has probably been underestimated in the previous calculations. However, applications of the former values, for instance in ecosystem health assessment, where exergy is used as ecological indicator (referred as exergy index) and in the development of structurally dynamic models, are still valid. Because the exergy calculations were applied only as relative measures.

This paper presents several indirect methods to determine $\beta$-values. It is shown that the $\beta$-values are well correlated to the age of the organisms (mya), to the number of cell types, to the minimum DNA-content, to the ratio non-coding genes versus total number of genes [Mattick, J.S., 2003. Challenging the dogma: the hidden layer of non-protein-coding RNAs in complex organisms. Bioassays 25, 930-939.] and to the $\beta$-values, determined by Fonseca et al. on basis of the total amount of DNA. Indirect determinations were therefore able to expand and improve the previous list of $\beta$-values. The previous list had only 19 values, while the list based on the whole-genome project has $16 \beta$-values. The expanded list presented in this paper contains 56 $\beta$-values. To reduce the uncertainty of the values, although assuming an apparent loss of discriminating power, it was decided to lump some organisms together in one group when it was know from the evolutionary tree that the organisms were closely related. It implies that the averages of $\beta$-values determined by different methods were applied, which should give a higher certainty.
\end{abstract}

\footnotetext{
* Corresponding author. Tel.: +45 35306281; fax: +45 35306013.

E-mail address: sej@dfuni.dk (S.E. Jørgensen).
} 
The result is a list with $45 \beta$-values, that hopefully will improve the use of $\beta$-values to calculate the exergy for assessment of ecosystem health and for the development of structurally dynamic models.

(C) 2004 Elsevier B.V. All rights reserved.

Keywords: Exergy; DNA; Genes; Evolution; Complexity

\section{Introduction}

In the last two decades, several mathematical functions have been proposed as holistic ecological indicators, intending (a) to express emergent properties of ecosystems arising from self-organisation processes in the run of their development, and (b) to act as orientors (goal functions) in models development. Such proposals resulted from a wider application of theoretical concepts, following the assumption that it is possible to develop a theoretical framework able to explain ecological observations, rules, and correlations on basis of an accepted pattern of ecosystem theories (Jørgensen and Marques, 2001). Exergy (Jørgensen and Mejer, 1979; Jørgensen, 1981), a concept derived from thermodynamics, which can be seen as a measure of the maximum amount of work that the system can perform when it is brought into thermodynamic equilibrium with its environment has been tested in several studies.

If exergy is calculated only from the chemical potentials, which are extremely dominant for ecosystems, the following expression is valid with good approximation:

exergy $=\mathrm{Ex}=R T \sum_{i=n}^{i=0}{ }^{i} C_{i} \ln C_{i} / C_{i 0}$.

where component 0 represents all the inorganic components, $n=1$ corresponds to detritus and $i \geq 2$ are the organisms, while $C_{i}$ is the concentration of the $i$ th component in the ecosystem and $C_{i 0}$ the same component at thermodynamic equilibrium. $\beta \equiv \ln C_{i} / C_{i 0}$, has previously (see Jørgensen et al., 1995, 2000; Jørgensen, 2002) been calculated for several organisms based upon the number of non-nonsense (coding) genes. It is assumed that an organism is represented by the enzymes, which determine the life processes and that $C_{i 0}$ can be calculated from the probability of random formation of these enzymes. The coding genes are considered blueprints of life. The calculations are based on the central dogma: DNA makes RNA, RNA makes proteins and proteins do almost the real work of biology. This idea is consistent with Boltzmann's expression for free energy of information $=R T \ln W$, where $W$ is the number of possible microstates. Fonseca et al. (2000) has proposed to use the total content of DNA based on the assumption that all DNA molecules represent information, but the organisms contain also junk genes, that are non-functional and the amount of coding DNA does not scale with complexity of the organisms (Mattick, 2003). However, as pointed out by Eddy (2001), the remaining DNA is not all junk, as it was assumed previously. Many hidden genes work through RNA and some of them play a major role in the control, maintenance and development of organisms.

Slowly but certainly we are realizing that there are non-coding genes that are clearly functional. Therefore to avoid confusion, we ought not to talk about genes anymore but call them transcriptional units to indicate the segments that are transcribed to RNA and have a function opposite to junk DNA. We do not yet know all the functions of DNA, but if we would know the number of transcriptional units of the various organisms we could find better $\beta$-values. The core question is: how can we account for the unappreciated power of RNA? Surveys of human DNA have found an almost equal number of genes and other transcriptional DNA-segments, sometimes called pseudogenes, and of defective copies and functional genes. In other words, if we would know for an organism the fraction of DNA, that is coding, the fraction that is transcriptional units with other functions and junk DNA, we could find a better $\beta$-value based on the same principles for computation of the $\beta$-value as previously applied.

What can we do until we have gained sufficient knowledge to allow calculations of much more accurate $\beta$-values? Fortunately, the $\beta$-values are applied relatively either as holistic indicators for ecosystem health (Jørgensen, 1998, 2001, 2002; Marques et al., 1997, 
1998, 2003; Xu et al., 2000,) or as weighting factors in structurally dynamic modelling (Jørgensen, 1998, 2002). The structurally dynamic modelling approach has now been used successfully in 18 case studies (see also Zhang et al., 2003a, 2003b) and the applied $\beta$ values have at the best been relative, very approximate estimations. We can, however, probably from these experiences conclude that the structurally dynamic approach is robust in the sense that it is essential that the weighting factors reflect the relative and approximate complexity of the organisms, but an extreme discriminating power is not essential, provided that the less complex organisms have much lower $\beta$-values. Anyway, it would be beneficial to have better $\beta$-values and particularly to get a longer list of $\beta$-values that to a higher extent could distinguish between groups of species or families. The results (Eichler and Sankoff, 2003) of ongoing whole-genome projects have therefore be applied to give improved $\beta$-values. Moreover, this paper has attempted to expand the list of $\beta$-values on the basis of other applicable measures of the organism complexity.

\section{Important correlations between $\beta$-values and other measures of organism complexity}

It is assumed that the $\beta$-values presently applied are only relatively and approximately correct, although the latest results of the ongoing whole-genome projects has been applied to improve the $\beta$-values. It will probably be possible in the future to improve considerably the $\beta$-values as a result of our considerations in this paper,
Table 1

$\beta$-values found on basis of the ongoing whole-genome sequencing project

\begin{tabular}{lclc}
\hline Organism & $\begin{array}{l}\text { Genome } \\
\text { size }(\mathrm{Mb})\end{array}$ & Repeat (\%) & $\beta$-value \\
\hline Human & 2900 & 46 & 2149 \\
House mouse & 2500 & 38 & 2127 \\
Tiger puffer fish & 400 & $<10(9$ is applied $)$ & 499 \\
Sea squirt & 155 & 10 & 191 \\
Malaria mosquito & 280 & 16 & 322 \\
Fruit fly & 137 & 2 & 184 \\
Nematode worm & 97 & $<1(0.5$ is applied $)$ & 133 \\
Human malaria Parasite & 23 & $<1(0.5$ is applied $)$ & 31 \\
Rodent malaria Parasite & 25 & $<1(0.5$ is applied $)$ & 34 \\
Social Amoebe & 34 & $<1(0.5$ is applied $)$ & 46 \\
Intracellular parasite & 34 & $<1(0.5$ is applied $)$ & 46 \\
Brewer's yeast & 12 & 2.4 & 15.9 \\
Fission yeast & 13.8 & 0.35 & 18.8 \\
Microsporidium, parasite & 2.5 & $<0.1$ & 3.4 \\
Mustard weed & 125 & 14 & 147 \\
Rice & 400 & $?(50$ is applied $)$ & 275 \\
\hline
\end{tabular}

when we have more knowledge about the transcriptional units of various organisms. Table 1 provides an overview of the results of the whole-genome sequencing projects and the $\beta$-values calculated on basis of the number of $\mathrm{Mb}$ and the $\%$ of repeating sequences. The exergy of organisms is found as the exergy of detritus + a contribution from the much lower $C_{i 0}$, for organisms. The much lower concentration (see Jørgensen, 2002) is found from the probability that the amino acids have the right sequence. The probability corresponds to $20^{\text {number of nucleotides }(1-\text { number of repeating genea) } / 3}$ because there are 20 different amino acids and three nucleotides determine one amino acid.

The exergy can now be found (see also Jørgensen et al., 2000) from:

$$
\frac{\mathrm{Ex}_{\text {virus }}}{R T}=7.34 \times 10^{5} C_{i}+C_{i} \ln 20_{\text {(exergy of detritus) }}^{\text {number of nucleodites (1-number of repeating genes) } / 3}
$$

$$
\beta=1+\frac{\ln 20 \text { (number of nucleotides }(1-\text { number of repeating genes) }}{3 \times 7.34 \times 10^{5}}
$$

As $\ln 20 \approx 3$, we get:

$$
\beta=1+\frac{\text { (number of nucleotides }(1-\text { number of repeating genes) }}{7.34 \times 10^{5}}
$$

It could be argued that the amount of genes would represent all the information but as we do not know all the 
Table 2

Relationships between $\beta$-values and other complexity measures (named concept) used to adjust or find new $\beta$-values

\begin{tabular}{llll}
\hline Concept & Relationship & $R$-value & Explanation \\
\hline NCT & $\beta=10.9$ NCT -9.06 & 0.83 & Increasing NCT with increasing complexity \\
r-DNA & $\ln \beta=5.44$ r-DNA +1.62 & 0.83 & Other functions becomes more important with increasing complexity \\
min-DNA & $\beta=12.0+1000$ min-DNA & 0.80 & Min-DNA represents coding genes \\
Age & $\beta=2601-385$ ln age & 0.84 & Time arrow for evolution (NB age $\leq 700$ mill.y) \\
$\beta$-Fon & $\beta=84.8+1.19 \beta$-Fon & 0.92 & Increasing DNA with increasing complexity (NB $\beta$-Fon $\geq 100)$ \\
\hline
\end{tabular}

functions of genes in details and a significant part of the genes are coding for amino acids, it has been decided to translate the genes to the information embodied in the amino acid sequence, which is slightly lower than the information in the genes because only 20 codes are needed for selection of the right amino acid in the sequence, while $4 \times 4 \times 4=64$ codes are available from three nucleotides.

Table 1 represents thereby $\beta$-values that are better supported than the previously applied $\beta$-values. Fur- thermore, this new list of $\beta$-values (Table 1) can be expanded, when we utilize all the available measures of organism complexity. Ladegaard et al. (submitted for publication) has found that there are correlations between the $\beta$-values on the one hand and on the other the number of cell types (abbreviated NCT), the ratio non-coding DNA to total DNA (Mattick, 2003) (abbreviated r-DNA), the minimum total DNA in a group of species (min-DNA), the age of the species (abbreviated age) and the $\beta$-values found by Fonseca et al. (2000)

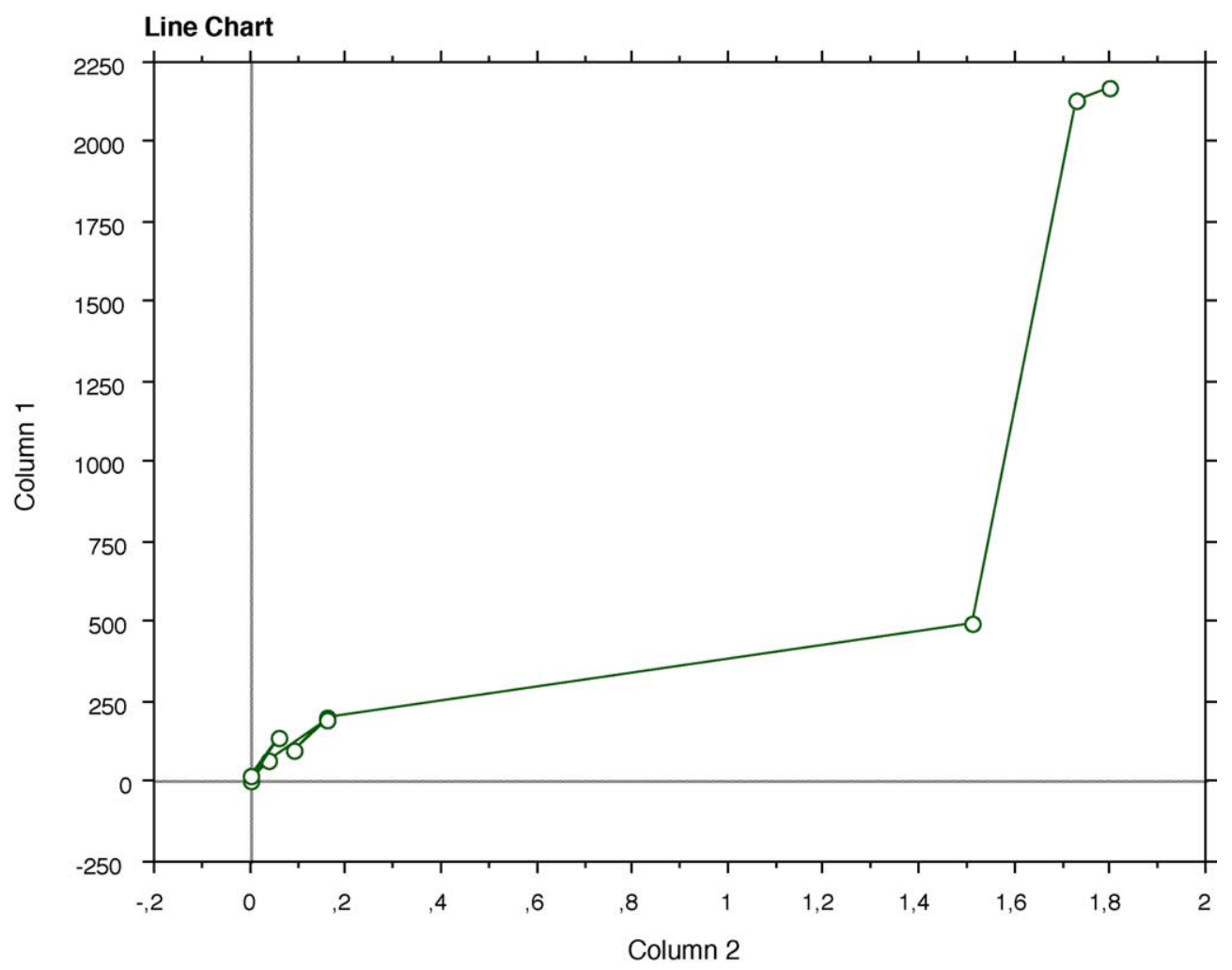

Fig. 1. The $\beta$-value ( $y$-axis, column 1) for a number of species or classes of species is plotted vs. the minimum total DNA ( $x$-axis, column 2 ). It is preferable to use this figures instead of the equation in Table 2. 


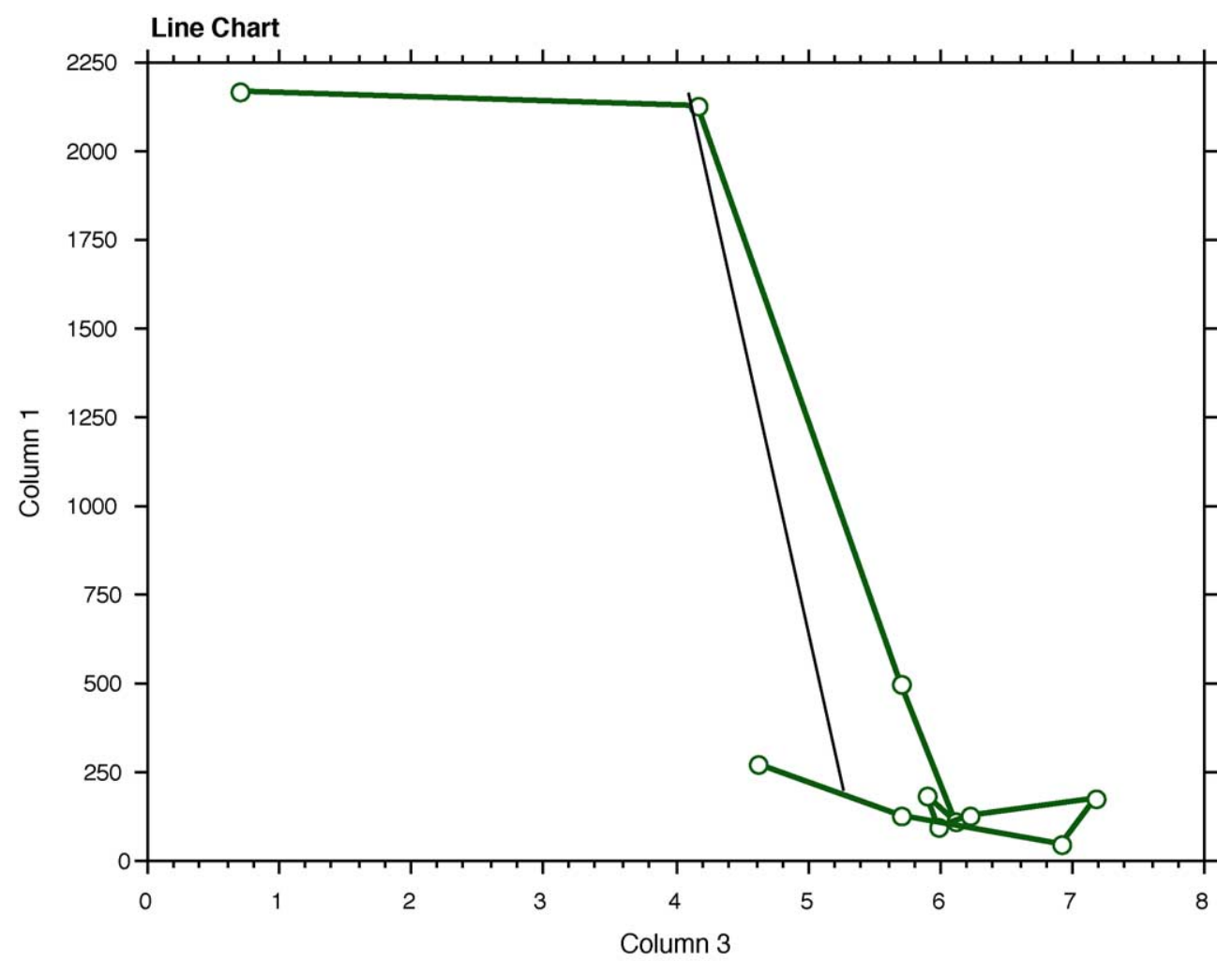

Fig. 2. The $\beta$-value ( $y$-axis, column 1) is plotted vs. the ln age ( $x$-axis, column 3 ) of various species or group of species. It is preferable to use this figure instead of the equation in Table 2. The thin line should be applied for ln age from 4.3 to 5.3.

(abbreviated $\beta$-Fon) based upon the determination of the total nuclear DNA. The equations used to cover the correlations are shown in Table 2. For two relationships are used the line chart namely for the minimum total DNA and the ln age plots. Both plots are associated with taxonomic group's emergence and the evolution and the relatively very rapid evolution from 600 to about 400 million years ago when many new species evolved makes a linear plot unrealistic. The two plots are shown as Figs. 1 and 2, respectively.

\section{An expanded and slightly improved $\beta$-values table}

If we take into account the number of cell types, the age of species, the ratio non-coding DNA to total DNA, the minimum nuclear DNA and the Fonseca et al. (2000) list of $\beta$-values, it becomes possible on ba- sis of the relationships in Table 2 and Figs. 1 and 2 to find unknown $\beta$-values or find alternative $\beta$-values that may adjust the present $\beta$-values. An expanded $\beta$-value table can therefore be made with these relationships in hand. Table 3 shows the expanded $\beta$-value table. It is indicated in the table whether the $\beta$-value is based on Table 1, or calculated from NCT, r-DNA, min-DNA, age or $\beta$-Fon. More than two indications mean that the average value of two or more found values is applied (shown in the last columns). Vertebrates have indicated in brackets the values that would result from NCT, r-DNA, min-DNA, age and/or $\beta$-Fon. These values have, however, been used to find the correlations and can therefore not be considered "new values", but they support to a certain extent the level of the previously applied $\beta$-values.

The $\beta$-value for virus is based upon the information, that its nucleic acid consists of approximately 6000 nucleotides (Dürr et al., 2002), which implies that it can 
Table 3

Extended and improved list of $\beta$-values, based on Table 1 the relationships in Table 2 and Figs. 1 and 2

\begin{tabular}{|c|c|c|}
\hline Organism & $\begin{array}{l}\text { Conversion } \\
\text { factor }(\beta)\end{array}$ & $\begin{array}{l}\text { Found respectively from } \\
\text { and explanation }\end{array}$ \\
\hline Virus & 1.01 & $\begin{array}{l}\text { Number of amino acids } \\
\text { coded by the DNA }\end{array}$ \\
\hline Minimal cell & 5.8 & r-DNA, NCT \\
\hline Bacteria & 8.5 & 20.9 \\
\hline Algae & 20 & NCT \\
\hline Archaea & 13.8 & min-DNA, average \\
\hline Protists & 21 & NCT \\
\hline Diatoms & 66 & NCT \\
\hline Yeast & 17.4 & Table 1 \\
\hline Fungi & 61 & Age \\
\hline Protozoa, Amoebe & $31-46$ & Table 1 \\
\hline Prolifera & 97 & NCT, min-DNA, r-DNA \\
\hline Angiosperm & 147 & r-min \\
\hline Rhodophyta & 92 & NCT \\
\hline Bryophyta & 173 & NCT, min-DNA, average \\
\hline Pteridophyta & 146 & $\mathrm{NCT}$, min-DNA \\
\hline Psilophyta & 170 & NCT \\
\hline Pinus mono & 314 & NCT \\
\hline Mustard weed & 147 & Table 1 \\
\hline Rice & 275 & Table 1 \\
\hline Eudicot & 268 & NCT, r-DNA \\
\hline Monocot & 393 & r-DNA \\
\hline Placozoa & 35 & NCT \\
\hline Cnidaria & 91 & NCT, min-DNA, average \\
\hline Platyhelminthes & 120 & NCT \\
\hline Mesozoa & 30 & NCT \\
\hline Kinorhynch & 165 & NCT \\
\hline Gastrotric, MetI & 76 & Age \\
\hline Rotifera & 163 & NCT, min-DNA \\
\hline Gnahostom & 143 & NCT \\
\hline Gastrotric, MetII & 116 & NCT, min-DNA \\
\hline Ctenophora & 167 & NCT, min-DNA, average \\
\hline Entoprocta & 165 & NCT \\
\hline Nematoda (Worms) & 133 & Table 1 \\
\hline Nematina & 76 & Age \\
\hline Mollusc & 310 & $\beta$-Fon \\
\hline Gastropods & 312 & min-DNA \\
\hline Bivalve & 297 & $\min -\mathrm{DNA}$ \\
\hline Annelida (f.i. leeches) & 133 & NCT, min-DNA \\
\hline Brachiopods & 109 & $\min -\mathrm{DTA}$ \\
\hline Sea squirt & 191 & Table 1 \\
\hline Crustacean & 232 & min-DNA, $\beta$-Fon \\
\hline Coleoptera (Beetles) & 156 & min-DNA, $\beta$-Fon \\
\hline Diptera (Flies) & 184 & Table 1 \\
\hline Hemiptera & 159 & min-DNA \\
\hline Hymenoptera & 267 & $\min -\mathrm{DNA}$ \\
\hline Lepidoptera & 221 & $\min -\mathrm{DNA}$ \\
\hline Phasmida & 43 & r-DNA \\
\hline Mosquito & 322 & Table 1 \\
\hline Chordata & 246 & $\beta$-Fon, age \\
\hline Fish & 499 & Table 1 \\
\hline
\end{tabular}

Table 3 (Continued)

\begin{tabular}{lcl}
\hline Organism & $\begin{array}{l}\text { Conversion } \\
\text { factor }(\beta)\end{array}$ & $\begin{array}{l}\text { Found respectively from } \\
\text { and explanation }\end{array}$ \\
\hline Amphibians & 688 & min-DNA, age, $\beta$-Fon \\
Reptiles & 833 & $\begin{array}{l}\text { min-DNA, age, } \beta \text {-Fon } \\
\text { min-DNA, age, } \\
\beta \text { Birds }\end{array}$ \\
Mammals & 980 & $\begin{array}{l}\beta \text {-Fon + higher fat content } \\
\text { Monkeys }\end{array}$ \\
Anthropoid apes & 2127 & Age 1 \\
Humans & 2138 & Age \\
\hline
\end{tabular}

code for 2000 amino acids. Consequently, the exergy can be found (see Jørgensen et al., 2000) for virus from:

$$
\begin{aligned}
\frac{\text { Ex }_{\text {virus }}}{R T} & =7.34 \times 10^{5} C_{i}+C_{i} \ln 20^{2000} \\
& =7.40 \times 10^{5} C_{i}
\end{aligned}
$$

and

$\beta=\frac{7.40}{7.34}=1.01$

Table 3 contains $56 \beta$-values which represent significant increase in comparison to the previous list, which included only $19 \beta$-values, including detritus. $\beta$-values in Table 3 are higher than the previously applied ones, despite the fact that the number of genes is lower. The previous numbers were based on a coding of 700 amino acids per gene, which most probably is too low (see for instance Chapman and Higgins, 2001). The number is rather a few thousands. The previous $\beta$-values have extensively been used for assessment of ecosystem health and also for development of structurally dynamic models. A further comparison of the two sets of values will however reveal that the ratio between $\beta$-values for two different organisms is not very different in the two lists. Since the values only have been applied relatively, the previous comparisons of ecosystem health assessments and the previous structurally dynamic models remain valid.

The previous calculation of information exergy was constructed with assumption that ecosystem structure is build from organisms where interactions among them were not taken into considered (Bendoricchio and Jørgensen, 1997). This simplification is acceptable in modelling context and is in accordance with prevailing acceptance of the central dogma concept that states that the information of the living cell is stored in the DNA 
and flows to proteins through RNA but never in opposite direction (Crick, 1970). The exergy calculations are furthermore based upon Boltzmann's equation on the free energy of information: $\mathrm{Ex}=R T \ln W$, where $W$ is the number of microstates among which we do know the one which is valid.

It has, however, been shown that information is not solely stored just in genes or genome. Results of Ricard's study (2001) show that sequence information stored in the chromosomes does not represent the full information of cells. It was also shown that information can be transformed from protein to protein which is indeed at variance with the central dogma. This indicates that the information content of the metabolic network is much larger than the sequence information content of the genome. Therefore, total information of living cell cannot be identified only with genetic information but with information stored in biological networks ranging from cell and organism to ecosystem. Thus, we have to include the complexity measures based on information of biological networks.

Recent publications about network complexity have proofed that Shannon's communication theory
(Shannon, 1948) is not ideally suited for describing network information (Strogas, 2001; Fell and Wagner, 2000). Shannon theory relies upon the statistical correlation between discrete variables and on the so-called subadditivity principle (Richard, 2003). Studies of biological networks have proofed (Richard, 2001, 2003) that biological network does not fulfil the criteria on which Shannon theory relies. Biological networks have properties of integration, emergence, evolution and going away from thermodynamic equilibrium. All those properties violate subadditivity principle and biological network is not composed only from statistically correlated discrete variables.

Richard (2003) has shown some possible alternations of Shannon theory in order to be objectively applied to networks. He states that principle of subadditivity is not a necessary condition for network, and this allows him to calculate the information of network. Neglecting subadditivity principle gives more a clear concept of information which is more general than the concept of communication and can be defined as the ability of a system to associate some of its element to generate functions (to develop away from thermody-

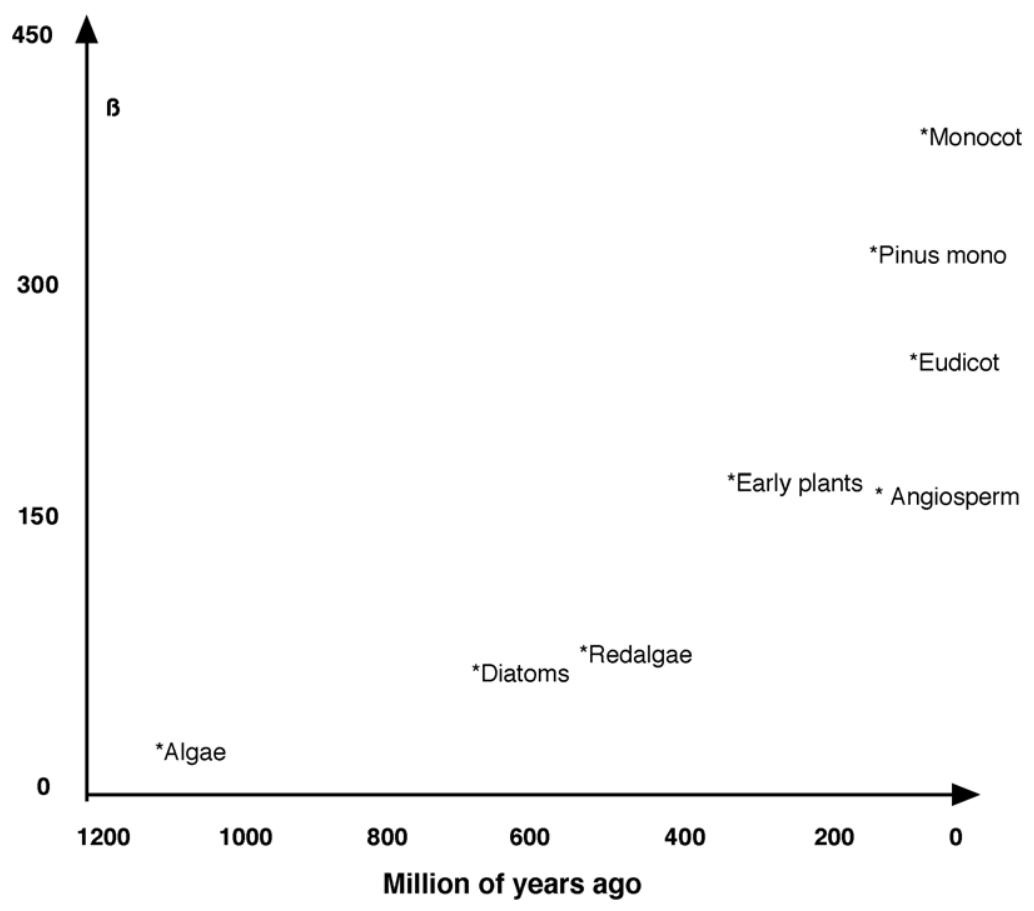

Fig. 3. Results from the application of an analysis of the evolution for plants are shown. The graph shows age vs. $\beta$-values according to Table 2 . 
namic equilibrium). In such a system the sum of joint entropy of the network is larger than the sum of individual entropies of its components. The system is complex and displays emergent effects associated with negative (lack of) information.

Further development and application of new concepts of Shannon theory which would be adopted to the properties of network information, has potential for successful continuation of our attempts for reliable description of life complexity (beta values) expressed by the exergy concept.

\section{Revisions of the $\beta$-table using evolutionary trees}

It is clear from the discussion in Section 1, that the $\beta$-values presented in Table 3 may be affected by the relatively high uncertainty, because they are determined indirectly - not on basis of a detailed knowledge about the functions of DNA-but from one of the indirect determination methods shown in Figs. 1 and 2 and Table 2. Estimations by two or more methods are nevertheless less uncertain. It has therefore been attempted to look at the evolution trees of the different taxonomic groups. In this case, species, group of species or families that are more closely related in terms of phylogeny than the $\beta$-values indicate, were lumped together in one group (McShea, 1996). The average $\beta$-values were applied to represent the organisms now included in the same group.

Results from the application of this analysis of evolutionary are shown in Figs. 3 and 4 and Table 4 provides the modified $\beta$-values. Table 4 contains $45 \beta$ values, including the $\beta$-value for detritus. The number of $\beta$-values has therefore more than doubled in comparison with the previous list (see for instance Jørgensen et al., 2000). It is proposed to use the $\beta$-values in Table 4 for ecosystem health assessment or development of structurally dynamic models, until an even better ta-

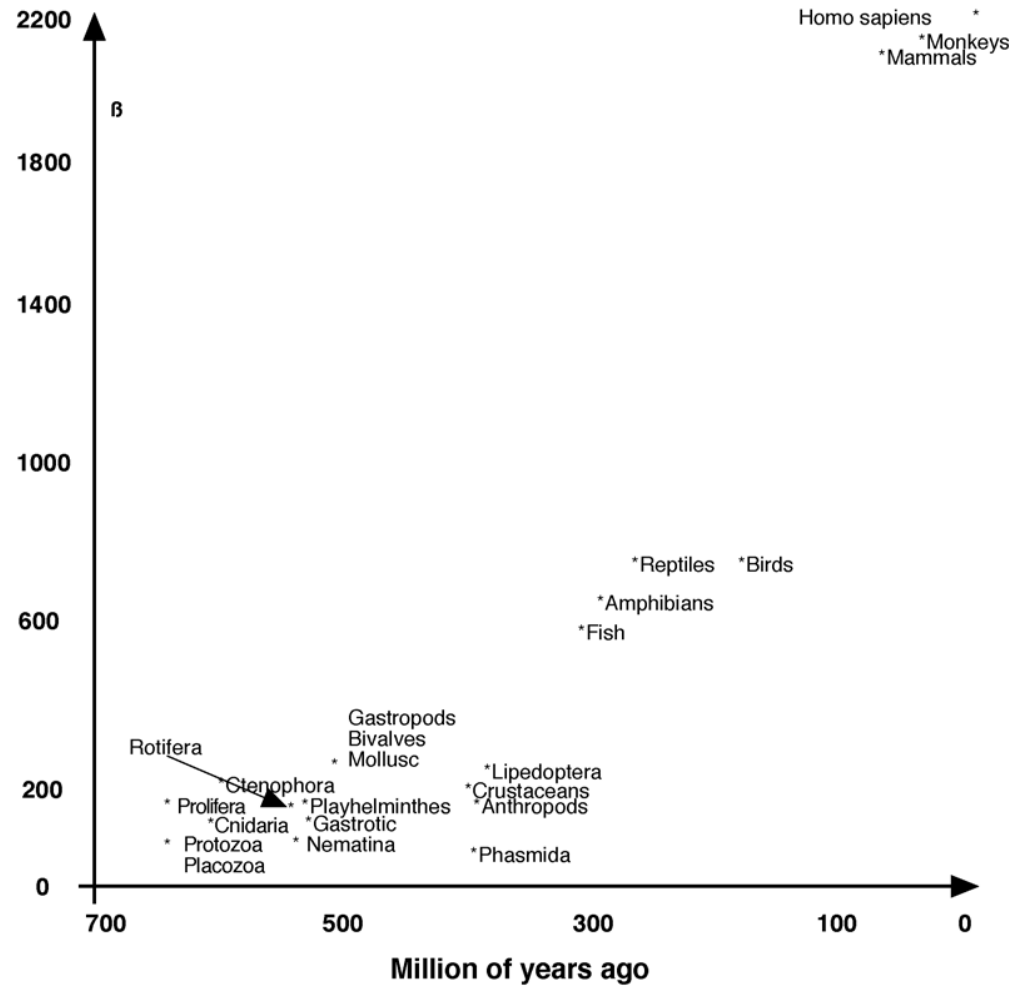

Fig. 4. Results from the application of an analysis of the evolution for animals are shown. The graph shows age vs. $\beta$-values according to Table 2 . 
ble can be produced. The values obtained are still relative and they are still uncertain, because they are not yet based on a completely detailed knowledge regarding the DNAs of all the organisms included in the list. The list is however probably more reliable than the list previously applied, because it is based on our latest detailed knowledge about the size of the genome for 16 organisms plus the latest knowledge about various indicators for the complexity of organisms. Because it includes more organisms, the $\beta$-values list in Table 4 is more user-friendly for usage in ecosystem health assessment and in modelling.

Table 4

List of updated $\beta$-values

\begin{tabular}{|c|c|c|c|}
\hline Detritus & & 1.00 & \\
\hline Virus & & 1.01 & \\
\hline Minimal cell & & 5.8 & \\
\hline Bacteria & & 8.5 & \\
\hline Archaea & & 13.8 & \\
\hline Protists & Algae & 20 & \\
\hline \multirow[t]{4}{*}{ Yeast } & & 17.8 & \\
\hline & & 33 & Mesozoa, Placozoa \\
\hline & & 39 & Protozoa, amoebe \\
\hline & & 43 & Phasmida (stick insects) \\
\hline \multirow[t]{5}{*}{ Fungi, moulds } & & 61 & \\
\hline & & 76 & Nemertina \\
\hline & & 91 & Cnidaria (corals, sea anemones, jelly fish) \\
\hline & Rhodophyta & 92 & \\
\hline & & 97 & Gastroticha \\
\hline \multirow[t]{30}{*}{ Prolifera, sponges } & & 98 & \\
\hline & & 109 & Brachiopoda \\
\hline & & 120 & Platyhelminthes (flatworms) \\
\hline & & 133 & Nematoda (round worms) \\
\hline & & 133 & Annelida (leeches) \\
\hline & & 143 & Gnathostomulida \\
\hline & Mustard weed & 143 & \\
\hline & & 165 & Kinorhyncha \\
\hline & Seedless vascular plants (incl. ferns) & 158 & \\
\hline & & 163 & Rotifera (wheel animals) \\
\hline & & 164 & Entoprocta \\
\hline & Moss & 174 & \\
\hline & & 167 & Insecta (beetles, flies, bees, wasps, bugs, ants) \\
\hline & & 191 & Coleodiea (Sea squirt) \\
\hline & & 221 & Lipidoptera (buffer flies) \\
\hline & & 232 & Crustaceans \\
\hline & & 246 & Chordata \\
\hline & Rice & 275 & \\
\hline & Gynosperms (inl. pinus) & 314 & \\
\hline & & 310 & Mollusca, bivalvia, gastropodea \\
\hline & & 322 & Mosquito \\
\hline & Flowering plants & 393 & \\
\hline & & 499 & Fish \\
\hline & & 688 & Amphibia \\
\hline & & 833 & Reptilia \\
\hline & & 980 & Aves (Birds) \\
\hline & & 2127 & Mammalia \\
\hline & & 2138 & Monkeys \\
\hline & & 2145 & Anthropoid apes \\
\hline & & 2173 & Homo Sapiens \\
\hline
\end{tabular}




\section{Conclusive and closing remarks}

It is clear that we do not have the knowledge that is needed to find the correct $\beta$-values for calculation of an exergy index (or we may call it, the index for the distance to the thermodynamic equilibrium) for an ecosystem model. In fact, the non-coding genes are not all junk information; but some may according to the latest results have a function which is important for the health of the organisms or as director for the organism development (Mattick, 2003). Therefore, it is wrong only to use the non-nonsense $=$ the coding genes. The previous found $\beta$-values are therefore most probably too small as they only account for the non-nonsense genes in estimating the $\beta$-values. On the other side, we can anyhow only find relative values, and as the applications of the previous $\beta$-values for the assessment of ecosystem health and in development of structurally dynamic models have been satisfactorily robust, the previously obtained results are valid; but the values should of course be updated when new knowledge is available. For this purpose, a more detailed knowledge on (a) the genome for 16 organisms, (b) number of cell type, (c) the ratio nonsense DNA to total DNA, minimum DNA have together with Fonseca's $\beta$-values been applied to get a more discrete and reliable list of $\beta$ values (see Tables 1 and 3 ). Table 3 has been calibrated toward the evolutionary trees, which has given occasion to some adjustment of the $\beta$-values (see Table 4). Consequently, it is at this stage advisable to use the values in Table 4 to estimate an exergy index for assessment of ecosystem health and for development of structurally dynamic models. For instance, zooplankton organisms, previously lumped simply in one group named zooplankton, can now be analysed using significantly more detailed list of $\beta$-values, which may be of importance for the further development of structurally dynamic models for aquatic ecosystems. The present list (Table 4) must, however, be permanently updated, as more certain measures of the information embodied in the organisms and about the complete genome size become available.

\section{References}

Bendoricchio, G., Jørgensen, S.E., 1997. Exergy as goal function of ecosystem dynamic. Ecol. Model. 102, 5-15.
Chapman, K.E., Higgins, S.J., 2001. Essays in Biochemistry. Regulation of Gene Expression. Portland Press, 130 pp.

Crick, F.C., 1970. Central dogma of molecular biology. Nature 227, 561-563.

Dürr, H.P., Popp, F.A., Schommers, W., 2002. What is Life?. World Scientific, New Jersey, 372 pp.

Eddy, S.R., 2001. Non-coding RNA genes and the modern RNA world. Nat. Rev. Genet. 2, 919-929.

Eichler, E.E., Sankoff, D., 2003. Structural dynamics of eukaryotic chromosome evolution. Science 301, 793-797.

Fell, D.E., Wagner, A., 2000. The small-world of metabolism. Nat. Biotechnol. 18, 1121-1122.

Fonseca, J.C., Marques, J.C., Paiva, A.A., Freitas, A.M., Madeira, V.M.C., Jørgensen, S.E., 2000. Nuclear DNA in the determination of weighing factors to estimate exergy from organisms biomass. Ecol. Model. 126, 179-189.

Jørgensen, S.E., Mejer, H., 1979. A holistic approach to ecological modelling. Ecol. Model. 7, 169-189.

Jørgensen, S.E., 1981. Exergy as a key function in ecological models. In: Mitsch, W., Bosserman, R.W., Klopatek, J.M. (Eds.), Energy and ecological modelling. Developments in Environmental Modelling. Elsevier, Amsterdam, pp. 587-590.

Jørgensen, S.E., 1998. Exergy as orientor for the development of ecosystems. In: Ulgiati, S. (Ed. in chief), Brown, M.T., Giampietro, M., Herendeen, R.A., Mayumi, K. (associate Eds.), Proceedings of the International Workshop on Advances in Energy Studies and Energy Flows in Ecology and Economy. Porto Venere, Italy, May 26/30, MUSIS, ROMA, pp. 371-402.

Jørgensen, S.E., 2001. Recent developments in system ecology. In: Matthies, M., Malchow, H., Kriz, J. (Eds.), Integrative System Approaches to Natural and Social Dynamics. Springer-Verlag, pp. $155-170$.

Jørgensen, S.E., Marques, J.C., 2001. Thermodynamics and ecosystem theory, case studies from hydrobiology. Hydrobiologia 445, $1-10$.

Jørgensen, S.E., Nors Nielsen, S., Mejer, H., 1995. Emergy, environ, exergy and ecological modelling. Ecol. Model. 77, 99-109.

Jørgensen, S.E., Patten, B.C., Straskraba, M., 2000. Ecosystems emerging: 4. Growth. Ecol. Model. 126, 249-284.

Jørgensen, S.E., 2002. Integration of Ecosystem Theories: A Pattern, vol. 432, 3rd ed. Kluwer Academic Publishing Company, Dordrecht, The Netherlands.

Ladegaard, N., Debeljak, M., Jørgensen, S.E., Complexity measurements of ecosystems. Ecol. Model., submitted for publication.

Marques, J.C., Pardal, M.A., Nielsen, S.N., Jørgensen, S.E., 1997. Analysis of the properties of exergy and biodiversity along an estuarine gradient of eutrophication. Ecol. Model. 102, 155-167.

Marques, J.C., Pardal, M.A., Nielsen, S.N., Jørgensen, S.E., 1998. Thermodynamic orientors: exergy as a holistic ecosystem indicator: a case study. In: Müller, F., Leupelt, M. (Eds.), Ecotargets, Goal Functions and Orientors. Theoretical Concepts and Interdisciplinary Fundamentals for an Integrated, System-based Environmental Management. Springer-Verlag, Berlim, pp. 87-101 (Chapter 2.5).

Marques, J.C., Nielsen, S.N., Pardal, M.A., Jørgensen, S.E., 2003. Impact of eutrophication and river management within a framework of ecosystem theories. Ecol. Model. 166, 147-168. 
Mattick, J.S., 2003. Challenging the dogma: the hidden layer of non-protein-coding RNAs in complex organisms. Bioassays 25, 930-939.

McShea, D.W., 1996. Metazoan Complexity and Evolution: Is there a Trend?.

Richard, J., 2001. Binding energy and the information content of some elementary biological processes. Sci. de la vie/Life Sci. 324, 297-304.

Richard, J., 2003. What do we mean by biological complexity? Sci. de la vie/Life Sci. 326, 133-140.

Shannon, C.E., 1948. A mathematical theory of communication. Bell Syst. Tech. J. 27 (379-423), 623-656.
Strogas, S.H., 2001. Exploring complex networks. Nature 410, 268-276.

Xu, F-L., Jørgensen, S.E., Tao, S., Li, B-G., 2000. Modelling the effects of ecological engineering on ecosystem health of a shallow eutrophic Chinese lake (Lake Chao). Ecol. Model. 117, 239260.

Zhang, J., Jørgensen, S.E., Tan, C.O., Beklioglu, M., 2003a. A structurally dynamic modelling Lake Mogan, Turkey as a case study. Ecol. Model. 164, 103-120.

Zhang, J., Jørgensen, S.E., Tan, C.O., Beklioglu, M., 2003b. Hysteresis in vegetation shift-lake Mogan Prognoses. Ecol. Model. 164, 227-238. 